\title{
Comparative data concerning aflatoxin contents in Bt maize and non-Bt isogenic maize in relation to human and animal health - a review
}

\author{
Vladimír Ostrý ${ }^{1,2}$, František Malíř ${ }^{2}$, Annie Pfohl-Leszkowicz ${ }^{3}$ \\ ${ }^{1}$ National Institute of Public Health in Prague, Center for Health, Nutrition and Food, Brno, Czech Republic \\ ${ }^{2}$ University of Hradec Kralove, Faculty of Science, Department of Biology, Hradec Králové, Czech Republic \\ ${ }^{3}$ University of Toulouse, INP/ENSA Toulouse, Department Bioprocess \& Microbial Systems, \\ Laboratory Chemical Engineering, Auzeville-Tolosane, France
}

Received June 6, 2014

Accepted November 26, 2014

\begin{abstract}
Transgenic Bt maize is a potentially important tool against insect pest in the EU and other countries. Bt maize (e.g. MON 810, Bt 11) which carries the Bt gene is highly resistant to larval feeding of European corn borer, stalk borer, and Southwestern corn borer, depending on Bt toxin ( $\delta$ toxin) production. Effective measures used to fight pests may often have positive side-effects in that they may also contribute to reducing mycotoxin concentrations. A systematic review has been used for the purposes of evaluating the studies on the reduction of aflatoxins in Bt maize. According to five studies, Bt maize has significantly lower concentrations of aflatoxins than nonBt maize hybrids, only one study has shown no significant effect of Bt maize. Other studies have shown mixed results (four studies). The results of these studies were influenced by the year of sampling or by using maize breeding lines selected for resistance to aflatoxin accumulation.
\end{abstract}

GMOs, transgenic maize, aflatoxins, mycotoxin reduction, food safety

Maize (Zea mays L.), one of the main cereals, is as source of food, forage, and processed products for industry. Maize is widely cultivated throughout the world, and a greater amount of maize is produced each year than any other grain. Worldwide production reached 875 million metric tons $(\mathrm{Mt})$ in 2012 - more than rice (718 million Mt) or wheat (675 million Mt). The United States produce $31 \%$ of the world's harvest; other top producing countries include China, Brazil, Mexico, Indonesia, India, France, and Argentina. Maize serves as a staple food for millions of people and also important source of feedstuffs for domesticated animals (FAOSTAT 2014), providing more than one-third of the calories and proteins in some countries.

The end-use products can be foods such as breakfast cereals, indigenous foods such as tortillas, tamales, tacos, enchiladas, and porridge, snack foods, and feedstuffs; approximately $70 \%$ of the world maize production is intended for animal feeds, or for industrial uses. The main maize exporting nations are the USA (53\%), China (19\%), and Argentina (17\%) (Chung et al. 2007).

Stored maize is a man-made ecosystem in which quality and nutritive changes occur because of interactions between physical, chemical and biological factors. Fungal spoilage and mycotoxin contamination are of major concern. Damaged grains are more prone to fungal invasion and, therefore, to mycotoxin contamination as well (Chulze 2010). Maize can be contaminated with several fungal species (e.g. Aspergillus and Fusarium). These are potential mycotoxin producers. They can produce aflatoxins, fumonisins and zearalenone, or ochratoxin A, zearalenone and aflatoxins in maize for human and animal consumption (Machinski and Soares 2000; Vargas et al. 2001; Strosnider et al. 2006). These mycotoxins belong to the most agriculturally important mycotoxins (Miller 1995; Santos et al. 2009).

Address for correspondence:

Vladimír Ostrý

National Institute of Public Health in Prague

Center for Health, Nutrition and Food

Palackého 3A 62, 61242 Brno, Czech Republic
Phone: +420515577523

Fax: +420 541212953

E-mail: ostry@chpr.szu.cz

http://actavet.vfu.cz/ 
Preventive strategies whose goal is to reduce the impact of mycotoxin in maize food and feed chains are based on using the hazard analysis critical control point systems (HACCP) approach. In order to reduce or prevent production of mycotoxins, drying during storage should take place soon after harvest and as fast as possible (Chulze 2010).

Therefore, this study focused on aflatoxins, a group of mycotoxins which are mainly produced by Aspergillus flavus and A. parasiticus (Ehrlich et al. 2007). Aflatoxins pose serious health risks to humans and domestic animals. They have both carcinogenic and hepatotoxic properties, depending on the duration and the level of exposure (IARC 1993; Pfohl-Leszkowicz 2009). Chronic dietary exposure to aflatoxins is a major risk factor with regard to hepatocellular carcinoma, particularly in areas where hepatitis B virus infection is endemic. Ingestion of higher doses of aflatoxins can result in acute aflatoxicosis, or in severe cases, even in fulminant liver failure (Fung and Clark 2004).

Transgenic Bt maize is genetically modified maize used around the world. Bt maize is a variant of maize that has been genetically altered to express one or more crystal (CRY) proteins (the insecticidal $\delta$ toxins) from the Bacillus thuringiensis soil bacteria which are toxic to certain members of the orders Lepidoptera or/and Coleoptera. Bt maize hybrids are highly resistant to European corn borer, stalk borer, and Southwestern corn borer and can also reduce damage caused by armyworm and corn earworm. Bt maize hybrids are a highly effective and economical alternative to conventional insecticide treatments, if targeted pest activity is at economically significant levels.

Bt maize was grown for the first time in the USA and Canada in 1997. Since then, the field area used for GM maize varieties increased to 57.4 million hectares in the year 2013, primarily in the USA, Argentina, Canada, South Africa, Uruguay, Egypt, the Philippines, and South America. Thirty two per cent of the maize production worldwide is now based on GM maize, which is a decrease of 3\% compared to the previous year. Two traits are expressed by today's GM maize cultivars: insect resistance and herbicide tolerance. More and more, cultivars are being grown that express both of these traits simultaneously (stacked genes). Plantings of Bt maize grew from about 8\% of US maize acreage in 1997 to $26 \%$ in 1999 , then fell to $19 \%$ in 2000 and 2001 , before climbing to $29 \%$ in 2003 , and $80 \%$ in 2014 . The increases in acreage share in recent years may be largely due to the commercial introduction of new Bt maize varieties resistant to the corn rootworm and the corn earworm, in addition to the European corn borer, which was previously the only pest targeted by Bt maize (GMO Compass 2014).

To date, the only type of GMO grown in the European Union is Bt maize. The first lines of GM maize were approved in the EU in 1997. Spain became Europe's first country to put it to use. Today, 79,269 hectares of Spanish maize production are genetically modified. The Spanish maize crop is used as animal feed. It is, in fact, Bt maize grown actually in four countries: the Czech Republic, Portugal, Slovakia, and Spain. Bt maize crop is used as animal feed (e.g. meal, silage, maize gluten), as raw material for the starch industry (e.g. a starch used in many foodstuffs and food additives) and in industry (e.g. ethanol fuel and biogas production) (GMO Compass 2014).

Anyone who intends to introduce GMOs into the environment for experimental purposes must first get authorisation from the relevant authority in the country where the release is planned. The authority will decide by assessing the environmental and health risks in line with the principles contained in Part B of Directive 2001/18/EC - deliberate release of GMOs into the environment. Up to now, $34 \mathrm{Bt}$ maize events were authorized in the EU. Current, authorized Bt maize events are shown in Table 1 (EC 2014).

Transgenic Bt maize MON 810 contains the Bt gene $(C r y I A b)$ which produces the CryIAb protein ( $\delta$ toxin) that is poisonous to insects in the Lepidoptera order, including the European corn borer (Ostrinia nubilalis Hübner). This $\delta$ toxin is activated in the alkaline environment of the insect's gut and then the insects die within 24-48 h. Effective measures taken to fight pests 
Table 1. Current Bt maize authorized in the EU (EC 2014)

\begin{tabular}{|c|c|}
\hline Bt maize & Inserted gene \\
\hline Bt11 & $C r y 1 A b^{\text {a }}$ \\
\hline $\mathrm{Bt} 11 \times \mathrm{GA} 21$ & $\operatorname{Cry} 1 A b^{\mathrm{a}}$ \\
\hline Bt11×MIR604 & $\operatorname{Cry} 1 A b^{\mathrm{a}}, \operatorname{Cry} 3 A^{\mathrm{b}}$ \\
\hline Bt11×MIR604×GA21 & $\operatorname{Cry} 1 A b^{\mathrm{a}}, \operatorname{Cry} 3 A^{\mathrm{b}}$ \\
\hline DAS1507 & $\operatorname{Cry} l F^{\mathrm{a}}$ \\
\hline DAS1507×DAS59122 & $\operatorname{Cry} 1 F^{\mathrm{a}}, \operatorname{Cry} 34 A b 1^{\mathrm{b}}, \operatorname{Cry} 35 A b 1^{\mathrm{b}}$ \\
\hline DAS1507×NK603 & $\operatorname{Cry} 1 F^{\mathrm{a}}$ \\
\hline DAS59122 & $\operatorname{Cry} 34 A b 1^{\text {b }}, C r y 35 A b 1^{\text {b }}$ \\
\hline DAS59122×DAS1507×NK603 & $\operatorname{Cry} 1 F^{\mathrm{a}}, \operatorname{Cry} 34 A b 1^{\mathrm{b}}, \operatorname{Cry} 35 A b 1^{\mathrm{b}}$ \\
\hline DAS59122×NK603 & Cry $34 A b 1^{\text {b }}, C r y 35 A b 1^{\mathrm{b}}$ \\
\hline MIR162 & $\operatorname{vip} 3 A a 20^{a}$ \\
\hline MIR604 & $\operatorname{Cry} 3 A^{\mathrm{b}}$ \\
\hline MIR604×GA21 & $\operatorname{Cry} 3 A^{\mathrm{b}}$ \\
\hline MON810 & $C r y l A b^{\mathrm{a}}$ \\
\hline MON863 & Cry $3 B b 1^{\text {b }}$ \\
\hline $\mathrm{MON} 863 \times \mathrm{MON} 810$ & $\operatorname{Cry} 3 B b 1^{\mathrm{b}}, C r y 1 A b^{\mathrm{a}}$ \\
\hline MON863×MON810×NK603 & $C r y 3 B b 1^{\mathrm{b}}, C r y 1 A b^{\mathrm{a}}$ \\
\hline MON863 ×NK603 & $C r y 3 B b 1^{\text {b }}$ \\
\hline MON88017 & Cry $3 B b 1^{\text {b }}$ \\
\hline MON88017×MON810 & $C r y 3 B b 1^{\mathrm{b}}, C r y 1 A b^{\mathrm{a}}$ \\
\hline MON89034 & $\operatorname{Cry} 1 A .105^{\mathrm{a}}, \mathrm{Cry} 2 \mathrm{Ab2} 2^{\mathrm{a}}$ \\
\hline MON89034×1507×MON88017×59122 & $\operatorname{Cry} 1 A .105^{\text {a }}, C r y 2 A b 2^{\text {a }}, C r y 1 F^{\text {a }}, C r y 3 B b 1^{\text {b }}, C r y 34 A b 1, C r y 35 A b 1^{\text {b }}$ \\
\hline MON89034×1507×MON88017 & 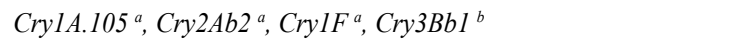 \\
\hline MON89034×1507×59122 & Cry1A.105 ${ }^{a}$, Cry2Ab2 $2^{a}, C r y 1 F^{a}, C r y 34 A b 1^{b}, C r y 35 A b 1^{b}$ \\
\hline MON89034×MON88017×59122 & $\operatorname{Cry} 1 A .105^{a}, \operatorname{Cry} 2 A b 2^{a}, C r y 3 B b 1^{b}, C r y 34 A b 1^{b}, C r y 35 A b 1^{b}$ \\
\hline $1507 \times$ MON88017×59122 & Cry $1 F^{a}, C^{2} y 3 B b 1^{b}, C^{2} y 34 A b 1^{b}, C r y 35 A b 1^{\mathrm{b}}$ \\
\hline MON89034×1507 & $\operatorname{Cry} 1 A .105^{a}, \operatorname{Cry} 2 \mathrm{Ab2}^{a}, \mathrm{Cry} 1 \mathrm{~F}^{a}$ \\
\hline MON89034×59122 & Cry1A.105 ${ }^{a}$, Cry $2 A b 2^{a}, C r y 34 A b 1^{b}, C r y 35 A b 1^{b}$ \\
\hline $1507 \times \mathrm{MON} 88017$ & $\operatorname{Cry} 1 F^{a}, \mathrm{Cry} 3 \mathrm{Bb} 1^{b}$ \\
\hline MON88017×59122 & Cry $3 B b 1^{b}, C r y 34 A b 1^{b}, C r y 35 A b 1^{\text {b }}$ \\
\hline MON89034×1507×NK603 & $\operatorname{Cry} 1 A .105^{\text {a }}, C r y 2 A b 2^{\text {a }} C r y 1 F^{\text {a }}$ \\
\hline MON89034×MON88017 & $\operatorname{Cry} 1 A .105^{\text {a }}, \operatorname{Cry} 2 A b 2^{\text {a }}, C r y 3 B b 1^{\text {b }}$ \\
\hline MON89034×NK603 & $\operatorname{Cry} 1 A .105^{\mathrm{a}}, \operatorname{Cry} 2 A b 2^{\text {a }}$ \\
\hline NK603×MON810 & $C r y 1 A b^{\mathrm{a}}$ \\
\hline
\end{tabular}

${ }^{a}$ Against the order of Lepidoptera

${ }^{\mathrm{b}}$ Against the order of Coleoptera

may often have positive side-effects in that they may also reduce concentrations of aflatoxins. Reducing aflatoxin presence can have important health as well as economic impacts, especially in less developed countries (Strosnider et al. 2006; Wu et al. 2004; Pazzi et al. 2006). In particular, potential health benefits resulting from aflatoxin reduction in $\mathrm{Bt}$ maize could introduce a new dimension to the debate on genetically modified crops (Wu 2006; Pazzi et al. 2006; Abbas et al. 2013). A review on the relationship between Bt maize and concentrations of aflatoxins in harvest was published by Wu (2007). 
The present review focuses on current information on $\mathrm{Bt}$ maize and the reduction of aflatoxins.

\section{Review procedures}

The following research question was formulated: "Is there a difference in reduction of aflatoxin concentrations in Bt maize hybrids compared to the correspondent isogenic plants?" Over 20 studies on aflatoxin contamination in Bt maize and non-Bt isogenic maize grown in USA and Italy published in scientific journals, were collected. A systematic review was applied for selection of relevant studies. Systematic review is a literature review focused on a research question, trying to identify, appraise, select, and synthesize all high quality research evidence relevant to that question. The qualitative criteria for the systematic review of individual studies have included independence and field trial design. Only 10 studies met our requirements (study independence and field trial design).

Wilcoxon paired one-sided signed rank test was used for purposes of statistical analysis of the results.

\section{Results}

Data resulting from comparing significant reduction $(P=0.0009766)$ of aflatoxins in $\mathrm{Bt}$ maize and non-Bt-maize are summarized in Table 2.

Bt maize had significantly lower concentrations of aflatoxins than non-Bt maize hybrids in 5 studies. These concentrations were $\times 2-10$ lower. One study showed no significant effect of Bt maize. Other studies showed mixed results (4 studies). The results of these studies depend on the year of sampling or on using maize breeding lines selected for resistance to aflatoxin accumulation.

Table 2. Results of comparison of significant reduction of aflatoxins in Bt maize and non-Bt-maize

\begin{tabular}{llllll}
\hline Study & Non-Bt maize $(\mathrm{mg} / \mathrm{kg})$ & Bt-maize $(\mathrm{mg} / \mathrm{kg})$ & Analytical method & Country of origin & \multicolumn{1}{c}{ References } \\
\hline 1 & 0.041 & 0.005 & Vicam Afla test & USA & Windham et al. 1999 \\
\hline 2 & $\mathrm{NSD}^{\mathrm{a}}$ & $\mathrm{NSD}^{\mathrm{a}}$ & HPLC & Italy & Masoero et al. 1999 \\
\hline 3 & $0.613\left(2000^{\mathrm{b}}\right)$ & $0.198\left(2000^{\mathrm{b}}\right)$ & Vicam Afla test & USA & Williams et al. 2002 \\
& $\mathrm{NSD}^{\mathrm{a}}\left(2001^{\mathrm{b}}\right)$ & $\mathrm{NSD}^{\mathrm{a}}\left(2001^{\mathrm{b}}\right)$ & & & \\
\hline 4 & 0.600 & 0.190 & Vicam Afla test & USA & Williams et al. 2005 \\
\hline 5 & $0.634\left(1998^{\mathrm{b}}\right)$ & $0.314\left(1998^{\mathrm{b}}\right)$ & Vicam & USA & Wiatrak et al. 2005 \\
& $\mathrm{NSD}^{\mathrm{a}}\left(1999^{\mathrm{b}}\right)$ & $\mathrm{NSD}^{\mathrm{a}}\left(2000^{\mathrm{b}}\right)$ & immunoaffinity & & \\
& $0.259\left(1999^{\mathrm{b}}\right)$ & $0.070\left(1999^{\mathrm{b}, \mathrm{c}}\right)$ & columns & & \\
\hline 6 & $\mathrm{NSD}^{\mathrm{a}}\left(2000^{\mathrm{b}}\right)$ & $\mathrm{NSD}^{\mathrm{a}}\left(1999^{\mathrm{b}}\right)$ & HPLC & & \\
\hline 7 & $0.045\left(2003^{\mathrm{b}}\right)$ & $0.012\left(2003^{\mathrm{b}}\right)$ & Veratox Aflatoxin & USA & Bruns and Abbas 2006 \\
\hline 8 & $\mathrm{NSD}^{\mathrm{a}}\left(2002,2004^{\mathrm{b}}\right)$ & $\mathrm{NSD}^{\mathrm{a}}\left(2002,2004^{\mathrm{b}}\right)$ & Neogen & & \\
\hline 9 & 0.084 & 0.013 & Vicam Afla test & USA & Williams et al. 2006 \\
\hline 10 & 0.774 & 0.211 & HPLC-FLD & USA & Abbas et al. 2008 \\
\hline
\end{tabular}

${ }^{a}$ Non-significant difference

${ }^{\mathrm{b}}$ Crop year

${ }^{\mathrm{c}}$ Maize breeding lines selected for resistance to aflatoxin accumulation 


\section{Discussion}

Although scores of experiments have examined the occurrence of aflatoxins in Bt maize and non-Bt maize, discussion continues regarding the food safety. Quantitative reviews of existing studies are crucial for purposes of better gauging risks and improving future risk assessments.

The primary consideration was not analytical determination but independence, and well designed (aspect) field studies were favoured.

Aflatoxins are produced by various types of Aspergillus (e.g. A. flavus, A. parasiticus, and $A$. nomius). Pre-harvest contamination by aflatoxins is a very complex problem linked to a multitude of biotic and abiotic factors. Therefore, a multi-pronged approach is needed in order to control aflatoxin contamination when field conditions are favourable for fungal contamination. Intense effort with regard to the control of aflatoxin contamination are devoted to the development of pre-harvest host plant-resistance (Cleveland et al. 2003). Aspergillus flavus enters the plants primarily through the stigma during flowering, and can contaminate maize even without insect damage. Apart from insect damage, drought stress and individual hybrid vulnerability are more important in determining aflatoxin contamination levels. The combination of drought stress, high temperature and humidity, and European corn borer kernel infestations, favours the production of aflatoxins in preharvest field maize (Smith and Riley 1992; Abbas et al. 2007; Kebede et al. 2012).

A significant reduction of aflatoxins in pre-harvest is obtained by optimization of plant resistance, fungicide use, and biocontrol (Cleveland et al. 2003). Studies on A. flavus, the agriculturally relevant producer of aflatoxins, have resulted in determining a well characterized biosynthetic pathway, as well as a basic understanding of the organism's life cycle. Unfortunately, these efforts have not resulted in production practices that substantially reduce aflatoxin contamination. Similarly, the use of agrochemicals (e.g. fungicides) results in very limited reduction of fungus or toxin. Thus, cultural management (fertility and irrigation) coupled with aggressive insect management provide the current state of the art for integrated aflatoxin management. The development of resistant hybrids appears to be a very promising technology, but commercial hybrids are still not available. Thus, biocontrol appears to be the most promising available avenue of reducing aflatoxin accumulation. Biocontrol employs non-toxigenic strains of $A$. flavus in order to reduce the incidence of toxin-producing isolates through competition. To maximize the effectiveness of biocontrol, thorough knowledge of the environmental factors influencing colonization and growth of A. flavus is needed. Aspergillus flavus does not only colonize plant tissue, but saprophytically grows in the soil on plant residues, as well. These residues serve as a reservoir for the fungus, allowing it to survive winter, and under favourable conditions to resume growth and release new conidia. The conidia can be transmitted through air or by insects to serve as a new inoculum on host plants or debris in the field. This complex ecology of $A$. flavus has been studied but our understanding remains behind what is known about the biosynthesis of the toxin itself. Our limited understanding of A. flavus soil ecology is in part due to limitations in evaluating $A$. flavus, aflatoxin, and the biosynthetic genes in the varying aspects of the environment. Current methods for assessing $A$. flavus and aflatoxin accumulation rely heavily on cultural and analytical methods that are low in throughput and technically challenging. Thus, in order to understand A. flavus ecology and environmental effects in contamination with a prospect of maximizing biocontrol efforts, it is necessary to understand current treatment effects and to develop methodologies capable of assessing fungal populations (Abbas et al. 2009; Wu and Khlangwiset 2010).

In Nigeria, the International Institute of Tropical Agriculture (IITA) has obtained provisional registration of the technology under the name Aflasafe ${ }^{\mathrm{TM}}$, a mixture of 4 atoxigenic strains of $A$. flavus of Nigerian origin. A single application of $10 \mathrm{~kg}$ of biopesticide 
Aflasafe $^{\mathrm{TM}}$ per hectare in 2009 in the period of 2-3 weeks before maize flowering was sufficient to prevent aflatoxin contamination during and after harvest, and even during grain storage. Aflasafe ${ }^{\mathrm{TM}}$ treatments provide long-term benefits and do not need have to be applied every year. Field testing of Aflasafe ${ }^{\mathrm{TM}}$ in Nigeria consistently showed a decrease of aflatoxin contamination in maize and in groundnut by $80-90 \%$ or even more (Donner et al. 2010; Bandyopadhyay 2010).

In conclusion, it can be stated that as for aflatoxins, the lowering effect of Bt maize is not as pronounced as in the case of fumonisins (Pazzi et al. 2006; Ostry et al. 2010; Abbas et al. 2013). There are, for the time being, few relevant field studies of the relationships between $\mathrm{Bt}$ maize and reduction of aflatoxin concentrations. The data can be confirmed in further research studies of comparing significant reduction of aflatoxins in Bt maize other than that with the Bt gene CryIAb and its non-genetically modified conventional counterparts.

\section{Acknowledgements}

The study was supported by the Ministry of Health, Czech Republic - Conceptual Development of Research Organization ("National Institute of Public Health - NIPH, IN 75010330").

\section{References}

Abbas HK, Accinelli C, Zablotowicz RM, Abel CA, Bruns HA, Dong Y, Shier WT 2008: Dynamics of mycotoxin and Aspergillus flavus levels in aging Bt and non-Bt corn residues under Mississippi no-till conditions. J Agric Food Chem 56: 7578-7585

Abbas HK, Shier TW, Cartwright RD 2007: Effect of temperature, rainfall and planting date on aflatoxin and fumonisin contamination in commercial Bt and non-Bt corn hybrids in Arkansas. Phytoprotection 88: 41-50

Abbas HK, Wilkinson JR, Zablotowicz RM, Accinelli C, Abel CA, Bruns HA, Weaver MA 2009: Ecology of Aspergillus flavus, regulation of aflatoxin production and management strategies to reduce aflatoxin contamination of corn. J Toxicol Toxins Rev 28: 142-153

Abbas HK, Zablotowicz RM, Weaver MA, Shier TW, Bruns HA, Bellaloui N, Accinelli C, Abel CA 2013: Implications of $\mathrm{Bt}$ traits on mycotoxin contamination in maize: Overview and recent experimental results. $\mathrm{J}$ Agri Food Chem 61: 11759-11770

Accinelli C, Abbas HK, Zablotowicz RM, Wilkinson JR 2008: Aspergillus flavus, aflatoxin occurrence and expression of aflatoxin biosynthesis genes in soil. Can J Microbiol 54: 371-379

Bandyopadhyay R 2010: Higher quality maize with Aflasafe. Appropriate Technol 37: 39-41

Bruns HA, Abbas HK 2006: Planting date effects on Bt and non-Bt corn in the mid-South USA. Agronomy J 98: 100-106

Cleveland TE, Dowd PF, Desjardins AE, Bhatnagar D, Cotty PJ 2003: United States Department of AgricultureAgricultural Research Service research on pre-harvest prevention of mycotoxins and mycotoxigenic fungi in US crops. Pest Manag Sci 59: 629-642

Chulze SN 2010: Strategies to reduce mycotoxin levels in maize during storage: a review. Food Addit Contam Part A 27:651-657

Chung OK, Park SH, Kim Y 2007: Concerted efforts in cereal grain quality improvement. In: Proceedings $\mathrm{N}^{\circ} 126$ of ICC International Conference on cereals and cereal products quality and safety, Rosario, Argentina, 23-26 September 2007, pp. 52-71

Directive 2001/18/EC of the European Parliament and of the Council of 12 March 2001 on the deliberate release into the environment of genetically modified organisms and repealing Council Directive 90/220/EEC 2001: Off J Eur Comm L 106: 1-38

Donner M, Atehnkeng J, Sikora RA, Bandyopadhyay R, Cotty PJ 2010: Molecular characterization of atoxigenic strains for biological control of aflatoxins in Nigeria. Food Addit Contam 27: 576-590

Ehrlich KC, Kobbeman K, Montalbano BG, Cotty PJ 2007: Aflatoxin-producing Aspergillus species from Thailand. Int J Food Microbiol 114: 153-159

EC (European Commision) 2014: EU register of GM food and feed. Available at: http://ec.europa.eu/food/dyna/ gm register/index en.cfm. Accessed June 6, 2014

FAOSTAT (Statistics at Food and Agriculture Organization of the United Nations) 2014: World maize production. Available at: http://faostat.fao.org. Accessed June 6, 2014

Fung F, Clark RF 2004: Health effects of mycotoxins: a toxicological overview. J Toxicol Clin Toxicol 42: 217-234

GMO Compass 2014: GM maize in the EU. Available at: http://www.gmo-compass.org. Last modified May 7 , 2013. Accessed June 6, 2014 
IARC (International Agency for Research on Cancer) 1993: IARC Monographs on the Evaluation of Carcinogenic Risks of Chemicals to Humans. Volume 56: Some naturally occurring substances: some food items and constituents, heterocyclic aromatic amines and mycotoxins: IARC, Lyon, $599 \mathrm{p}$.

Kebede HA, Abbas HK, Fisher DK, Bellaloui N 2012: Relationship between aflatoxin contamination and physiological responses of corn plants under drought and heat stress. Toxins 4: 1385-1403

Machinski M, Soares LMV 2000: Fumonisins $B_{1}$ and $B_{2}$ in Brazilian corn-based food products. Food Addit Contam 17: 875-879

Masoero F, Moschini M, Rossi F, Prandini A, Pietri A 1999: Nutritive value, mycotoxin contamination and in vitro rumen fermentation of normal and genetically modified corn $(\mathrm{Cry} 1 \mathrm{Ab})$ grown in northern Italy. Maydica 44: $205-209$

Miller JD 1995: Fungi and mycotoxins in grain: implications for stored product research. J Stored Prod Res 31: $1-6$

Ostry V, Ovesna J, Skarkova J, Pouchova V, Ruprich J 2010: A review on comparative data concerning Fusarium mycotoxins in Bt maize and non-Bt isogenic maize. Mycotox Res 26: 141-145

Pazzi F, Lener M, Colombo L, Monastra, G 2006: Bt maize and mycotoxins: the current state of research. Ann Microbiol 56: 223-230

Pfohl-Leszkowicz A 2009: Mycotoxins: risk factor of cancer. Afr J Cancer 1: $42-55$

Santos L, Marin S, Sanchis V, Ramos AJ 2009: Screening of mycotoxin multicontamination in medicinal and aromatic herbs sampled in Spain. J Sci Food Agric 89: 1802-1807

Smith MS, Riley TJ 1992: Direct and interactive effects of planting date, irrigation, and corn earworm (Lepidoptera: Noctuidae) damage on aflatoxin production in preharvest corn. J Econ Entomol 85: 998-1006

Strosnider H, Azziz-Baumgartner E, Banziger M, Bhat RV, Breiman R, Brune MN, DeCock K, Dilley A, Groopman J, Hell K, Henry SH, Jeffers D, Jolly C, Jolly P, Kibata GN, Lewis L, Liu X, Luber G, McCoy L, Mensah P, Miraglia M, Misore A, Njapau H, Ong CN, Onsongo MT, Page SW, Park D, Patel M, Phillips T, Pineiro M, Pronczuk J, Rogers HS, Rubin C, Sabino M, Schaafsma A, Shephard G, Stroka J, Wild C, Williams JT, Wilson D. 2006: Workgroup report: public health strategies for reducing aflatoxin exposure in developing countries. Environ Health Perspect 114: 1898-1903

Vargas EA, Preis RA, Castro L, Silva CMG 2001: Co-occurrence of aflatoxins $B_{1}, B_{2}, G_{1}, G_{2}$, zearalenone and fumonisin $\mathrm{B}_{1}$ in Brazilian corn. Food Addit Contam 18: 981-986

Wiatrak PJ, Wright DL, Marois JJ, Wilson D 2005: Influence of planting date on aflatoxin accumulation in Bt, non-Bt, and tropical non-Bt hybrids. Agron J 97: 440-445

Williams WP, Windham GL, Buckley PM, Daves CA 2002: Aflatoxin accumulation in conventional and transgenic corn hybrids infested with southwestern corn borer (Lepidoptera: Crambidae). J Agri Urb Entomol 19: $227-236$

Williams WP, Windham GL, Buckley PM, Perkins JM 2005: Southwestern corn borer damage and aflatoxin accumulation in conventional and transgenic corn hybrids. Field Crop Res 91: 329-336

Williams WP, Windham GL, Buckley PM, Daves CA 2006: Aflatoxin accumulation in corn hybrids infested at different growth stages with southwestern corn borer (Lepidoptera: Crambidae). J Agric Urban Entomol 23: 97-103

Williams WP, Windham GL, Krakowsky MD, Scully BT, Ni X 2010: Aflatoxin accumulation in Bt and non-Bt maize testcrosses, J Crop Improv 24: 392-399

Windham GL, Williams WP, Davis FM 1999: Effects of the southwestern corn borer on Aspergillus flavus kernel infection and aflatoxin accumulation in maize hybrids. Plant Dis 83: 535-540

Wu F, Miller JD, Casman EA 2004: Bt corn and mycotoxin reduction: an economic perspective. J Toxicol Toxin Rev 23: 397-424

Wu F 2006: Mycotoxin reduction in Bt corn: potential economic, health, and regulatory impacts. Transgenic Res 15: $277-289$

Wu F 2007: Bt corn and mycotoxin reduction. CAB Reviews: Perspectives in Agriculture, Vet Sci Nutr Nat Res 2:1-8

Wu F, Khlangwiset P 2010: Health and economic impacts and cost-effectiveness of aflatoxin-reduction strategies in Africa: case studies in biocontrol and postharvest interventions. Food Addit Contam 27: 496-509 